\title{
IZAZOVI LEGALIZACIJE GRAĐEVINA U LUKAMA NAUTIČKOG TURIZMA
}

Dr. sc. Sanja Ljubetić*

UDK: $347.799 .6: 349.414(497.5)$

351.711(210.5):349.414(497.5)

$347.218 .2: 347.799(497.5)$

349.414:797.1(497.5)

DOI: $10.3935 / z p f z .71 .5 .06$

Pregledni znanstveni rad

Primljeno: listopad 2021.

$U$ radu se analizira problematika $i$ izazovi s kojima se susreću investitori $u$ lukama nautičkog turizma prilikom pribave dozvola za postojeće građevine, koje slijedom povijesno neuređene pravne situacije nemaju potrebne dozvole. Posebna pozornost u radu posvećuje se problematici legalizacije građevina sukladno definiciji lučke suprastrukture sadržanoj u općim odredbama Zakona o pomorskom dobru $i$ morskim lukama. Daje se pregled i ocjena normativnog uređenja te postupanja u praksi kao i prijedlozi usmjereni boljoj pravnoj uređenosti navedenog područja.

Ključne riječi: pomorsko dobro, lučko područje, luke nautičkog turizma, legalizacija građevina

\section{UVOD}

S obzirom na nespornu ljepotu jadranske obale te mogućnost gradnje građevina na pomorskom dobru, pomorsko dobro već je desetljećima predmet interesa, posebice privatnih. A kako to obično biva, nerijetko se dogodi da taj privatni interes nije u skladu s onim što bi se imalo smatrati općim interesom. Tako su

* Dr. sc. Sanja Ljubetić, pravni zastupnik, Adriatic Croatia International Club, Rudolfa Strohala 2, 51000 Rijeka; sanja.ljubetic@aci-club.hr;

ORCID ID: orcid.org/0000-0002-0110-3998 
u javnosti sve češće pritužbe stanovnika priobalnih područja na nezakonito sagrađene objekte na pomorskom dobru i na nezakonito prisvajanje čitavih plaža i devastiranje morskog okoliša. ${ }^{1}$ Potreba uređenja odnosa koji nastaju uporabom pomorskog dobra za javne i privatne svrhe zapravo nije tendencija suvremenog doba. Naime, početak uređenja instituta pomorskog dobra i statusa građevina koje se nalaze na njemu datira još od rimskog prava. ${ }^{2}$ Kroz različite političke sustave i različita pravna uređenja obalno područje je (kao i preostali teritorij) često služilo javnoj vlasti samo kao objekt provođenja političke volje i kratkoročnih aspiracija države. Nebriga o evidentiranju pomorskog dobra u katastru i zemljišnim knjigama ogledala se i u činjenici da su se na nekretninama uz more nataložila desetljeća pravnih poslova i pravnih odnosa na temelju kojih su obavljana različita ulaganja, građenja s dozvolom i bez nje, a da se istodobno uopće nije registriralo da su to nekretnine na pomorskom dobru. ${ }^{3}$ Od sredine prošlog stoljeća kreće nagla urbanizacija priobalnog područja što pod budnim okom države, što u privatnom aranžmanu. ${ }^{4}$ Navedeno je stoga rezultiralo i gradnjom

1 S problemom devastacije morske obale zbog bespravne gradnje među mediteranskim državama posebice se ističe Grčka. O navedenome više vidi Ljubetić, S., Pomorsko dobro i zemliišne knjige, Pravni fakultet Sveučilišta u Zagrebu, Zagreb, 2019., str. 190 - 198. O tzv. mrtvom kapitalu prouzročenome neplanskom gradnjom u priobalnom području Grčke vidi više Potsiou, C.; Boulaka, I., Informal development in Greece: New legalisation for Formalization, the Chances for Legalization and the Dead Capital, International Federation of Surveyors, 2012., str. 1 - 19, dostupno na http:// www.fig.net/pub/fig2012/papers/ts09k/TS09K_potsiou_boulaka_5514.pdf (29. listopada 2021.).

2 O pravnom uređenju pomorskog dobra u rimskom pravu vidi više Vojković, G., Pomorsko dobro i koncesije, Hrvatski hidrografski institut, Split, 2003., str. 15 - 16.

3 Tako Hlača, V.; Nakić, J., Zaštita pomorskog dobra u Republici Hrvatskoj, Poredbeno pomorsko pravo, vol. 49, 2010., str. 500. Zbog navedenog (ne)uređenja do danas su otvorena brojna pitanja glede mogućnosti postojanja stvarnih prava na pomorskom dobru. Vidi više Jug, J., Stvarna prava na pomorskom dobru?, Zbornik Pravnog fakulteta Sveučilišta u Rijeci, vol. 34, br. 1, 2013., str. 277 - 305 i Bolanča, D., Problem stvarnih prava na pomorskom dobru (bitne novine hrvatskoga pomorskog zakonodavstva), Poredbeno pomorsko pravo, vol. 54, 2015., str. 327 - 358.

4 Do 1974. godine na pomorskom dobru moglo se stjecati pravo vlasništva na nekretninama namijenjenim za stanovanje, a sukladno tom zakonskom rješenju diljem hrvatske obale sagrađene su brojne kuće i zgrade; tako Jelavić, A., Pravni položaj pomorskog dobra, Naše more, vol. 59, br. 1-2, 2012., str. 31. U doktrini se upozorava da su neka stajališta o izgradnji građevina iz prošlog sistema danas ne samo neuporabljiva već i opasna. Tako je, primjerice, obuhvat građevinskog zemljišta koji je u suvremenom pravnom poretku moguće definirati samo geometrijski diskrecijskom odlukom javne vlasti mogao biti određen uporabom funkcionalnog kriterija kao zemljišta koje služi redovitoj uporabi zgrade, na koji način je javna vlast de facto 
brojnih bespravnih objekata uz obalu. ${ }^{5}$ Osamostaljenje države i nagli izlazak iz socijalističkog pravnog poretka te ulazak u kontinentalnoeuropski pravni krug ${ }^{6}$ donosi izmjene i za institut pomorskog dobra. U postojećem uređenju pomorsko dobro pripada u ustavnopravnu kategoriju dobra od općeg interesa koja u prvom redu označava posebnu zainteresiranost države i zajednice za to dobro, za njegovo uređenje, korištenje, zaštitu, nadzor i održavanje, upravo zbog njegove opće društvene važnosti. ${ }^{7}$ Pomorsko dobro tako je definirano kao opće dobro od interesa za Republiku Hrvatsku, koje čine unutarnje morske vode i teritorijalno more, njihovo dno i podzemlje te dio kopna koji je po svojoj prirodi namijenjen općoj upotrebi ili je proglašen takvim, kao i sve što je s tim dijelom kopna trajno spojeno na površini ili ispod nje. Predmetnim dijelom kopna smatra se: morska obala, luke, nasipi, sprudovi, hridi, grebeni, plaže, ušća rijeka koje se izlijevaju u more, kanali spojeni s morem, te u moru i morskom podzemlju živa i neživa prirodna bogatstva. ${ }^{8}$ Status dobra od interesa za Republiku Hrvatsku donosi i pojačanu pravnu zaštitu, stoga se ono upotrebljava ili koristi pod uvjetima i na način propisan ZPDML-om ${ }^{9}$, kao propisom donesenim s intencijom osiguravanja održivog i razrađenog pravnog režima pomorskog dobra.

Korištenje pomorskog dobra nužno uključuje i gradnju građevina i drugih objekata na pomorskom dobru. Ovisno o svrsi za koju se koristi pomorsko

provodila izvlaštenje glede preostalog djela zemljišta, vidi Gavella, N. u: Gavella, N.; Josipović T.; Gliha, I.; Belaj, V.; Stipković, Z., Stvarno pravo, II. izmijenjeno i dopunjeno izdanje, svezak 1., Narodne novine, Zagreb, 2007., str. 87, bilješka 76.

5 Problematika bespravne gradnje posebno je zastupljena na otoku Visu, koji je u bivšoj SFRJ bio predviđen kao jedna od lokacija smještaja nuklearne elektrane, zbog čega su vlasti poticale građane na gradnju objekata na tom otoku uz obećanje kasnijeg rješavanja pitanja dozvola za gradnju, do kojeg uslijed propasti bivše države nije došlo, vidi Hlača; Nakić, op. cit. u bilj. 3, str. 498, bilješka 12.

6 Pravni poreci kontinentalnoeuropskog pravnog kruga bitno se razlikuju od socijalističkih ponajprije prema tome na koji način gledaju problem odnosa pojedinca i društva, odnosno kako rješavaju problem javnog i privatnog. Pravni poreci kontinentalnoeuropskog pravnog kruga bitno su obilježeni time što središnje mjesto zauzima građanskopravno uređenje oko kojeg se i oblikuje pravni poredak. Tako Gavella, N. u: Gavella, N.; Alinčić, M.; Klarić, P.; Sajko, K.; Tumbri, T.; Stipković, Z.; Josipović, T.; Gliha, I., Hrvatsko građanskopravno uređenje i kontinentalnoeuropski pravni krug, 2. izdanje, Pravni fakultet, Zagreb, 1994., str. 7 - 8.

7 Tako Nakić, J., Pomorsko dobro - opće ili javno dobro?, Zbornik radova Pravnog fakulteta u Splitu, vol. 53, br. 3, 2016., str. 804.

8 Čl. 3. Zakona o pomorskom dobru i morskim lukama (dalje u tekstu: ZPDML), Narodne novine, br. 158/2003, 100/2004, 141/2006, 38/2009, 123/2011, 56/2016 i 98/2019.

9 Čl. 3. st. 1. ZPDML-a. 
dobro, razlikuje se i njegova izgrađenost. Tako od privremenih konstrukcija odnosno montažnih objekata možemo razlikovati građevine i druge objekte na pomorskom dobru kao sklopove koji su trajno povezani s pomorskim dobrom, što onda uključuje i posebnu regulaciju glede isprava kojima se dokazuje njihova zakonitost.

ZPDML, polazeći od razlikovanja lučkog područja kao područja morske luke, koje obuhvaća jedan ili više morskih i kopnenih prostora (lučki bazen), koje se koristi za obavljanje lučkih djelatnosti, a kojim upravlja lučka uprava, odnosno ovlaštenik koncesije ${ }^{10}$ te, s druge strane, izvanlučkog područja kao područja koje je određeno sa svime što ne bi pripadalo u prethodno navedeno, definira i objekte koji se nalaze na pomorskom dobru. Kao moguće građevine i druge objekte na pomorskom dobru ZPDML tako razlikuje lučku podgradnju (infrastrukturu) te lučku nadgradnju (suprastrukturu). Lučku podgradnju čine operativne obale i druge lučke zemljišne površine, lukobrani i drugi objekti infrastrukture (npr. lučke cestovne i željezničke prometnice, vodovodna, kanalizacijska, energetska, telefonska mreža, objekti za sigurnost plovidbe u luci i sl.). Lučku nadgradnju čine građevine sagrađene na lučkom području (upravne zgrade, skladišta, silosi, rezervoari i sl.). ${ }^{11}$ ZPDML izričito određuje ${ }^{12}$ i vlasničkopravni status tih objekata. Građevine i drugi objekti na pomorskom dobru koji su trajno povezani s pomorskim dobrom smatraju se pripadnošću pomorskog dobra. ${ }^{13} \mathrm{Na}$ pomorskom dobru ne može se stjecati pravo vlasništva ni druga stvarna prava po bilo kojoj

10 Granica lučkog područja ujedno je i granica pomorskog dobra. Čl. 2. st. 1. t. 4. ZPDML-a. Luka označava morsku luku, tj. morski i s morem neposredno povezani kopneni prostor s izgrađenim i neizgrađenim obalama, lukobranima, uređajima, postrojenjima i drugim objektima namijenjenim za pristajanje, sidrenje i zaštitu brodova, jahti i brodica, ukrcaj i iskrcaj putnika i robe, uskladištenje i drugo manipuliranje robom, proizvodnju, oplemenjivanje i doradu robe te ostale gospodarske djelatnosti koje su s tim djelatnostima u međusobnoj ekonomskoj, prometnoj ili tehnološkoj svezi, čl. 2. st. 1. t. 1. ZPDML-a.

11 Čl. 2. st. 1. t. 7. i 8. ZPDML-a.

12 U čl. 5. ZPDML-a.

13 ZPDML pri takvom određenju nije iskoristio mogućnost (prednost) koju mu je svojim općim odredbama dopustio Zakon o vlasništvu i drugim stvarnim pravima (Narodne novine, br. 91/1996, 68/1998, 137/1999, 22/2000, 73/2000, 129/2000, 114/2001, 79/2006, 141/2006, 146/2008, 38/2009, 153/2009, 143/2012 i 152/2014) u čl. 3. st. 4. i čl. 9. st. 4. glede pravnog razdvajanja zgrada i drugih građevina izgrađenih na općem dobru na temelju koncesije, s kojim izuzetkom ove građevine mogu predstavljati posebnu nekretninu dok koncesija traje; tako Perkušić, A.; Petrinović R.; Perkušić Z., Stjecanje i zaštita posjeda na pomorskom (općem) dobru - de lege lata - de lege ferenda (poseban osvrt na prijedlog novog Zakona o pomorskom dobru i morskim lukama), Poredbeno pomorsko pravo, vol. 49, 2010., str. 538. 
osnovi. Dakle, sukladno odredbama ZPDML-a nije sporna pravna sudbina građevina na pomorskom dobru. ${ }^{14}$

Ono što se u praksi pojavljuje kao sporno, a nije posebno uređeno odredbama ZPDML, jest pitanje ozakonjenja građevina na pomorskom dobru. Naime, u nastavku rada nije riječ o gradnji novih građevina, već o pravnom statusu postojećih građevina na pomorskom dobru.

Izgradnja građevina predmet je uređenja Zakona o gradnji ${ }^{15}$, odnosno Zakona o prostornom uređenju ${ }^{16} \mathrm{u}$ dijelu koji se odnosi na predradnje koje se moraju poduzeti glede izgradnje građevina. Zakon o gradnji građevinu određuje kao građenjem nastao i s tlom povezan sklop, izveden od svrhovito povezanih građevnih proizvoda sa ili bez instalacija, sklop s ugrađenim postrojenjem, samostalno postrojenje povezano s tlom ili sklop nastao građenjem ${ }^{17}$, dok postojeću građevinu određuje kao građevinu izgrađenu na temelju građevinske dozvole ili drugog odgovarajućeg akta i svaku drugu građevinu koja je prema tome ili posebnom zakonu s njom izjednačena. ${ }^{18}$

Građevine na pomorskom dobru obuhvaćaju sve one građevine koje se nalaze kako unutar ex lege pojasa pomorskog dobra od 6 metara $^{19}$, tako i one izgrađene $\mathrm{u}$ širem pojasu određenom sukladno prirodnom i funkcionalnom kriteriju. Građevine na pomorskom dobru, s obzirom na pravnu prirodu općeg dobra,

14 Na takvo određenje koje je postojalo i prije stupanja na snagu ZPDML-a upućuje i Vrhovni sud Republike Hrvatske u Rješenju, broj Gzz-131/03-2 od 2. srpnja 2003. godine, pritom ističući da je odredbom st. 1. čl. 51. Pomorskog zakonika (dalje u tekstu: PZ-a) (Narodne novine, br. 17/1994, 74/1994 i 43/1996) propisano da se na pomorskom dobru, kao res extra commercium, ne može stjecati ni pravo vlasništva ni drugo stvarno pravo po bilo kojoj osnovi, već da se ono može upotrebljavati, odnosno koristiti samo na temelju koncesije, a iz odredbe čl. 71. st. 2. i prijelaznih odredaba iz čl. 1038., 1039. i 1040. PZ-a proizlazi da su zgrade i građevine izgrađene na pomorskom dobru pripadnost pomorskog dobra, dostupno na: https://www.iusinfo. hr/sudska-praksa/VSRH2003GzzB131A2 (29. listopada 2021.).

15 Narodne novine, br. 153/2013, 20/2017, 39/2019 i 125/2019.

16 Narodne novine, br. 153/2013, 65/2017, 114/2018, 39/2019 i 98/2019. O prostornom planiranju na pomorskom dobru više vidi u: Ljubetić, S., Pomorsko dobro i luke nautičkog turizma, u: Zbornik 57. susreta pravnika u gospodarstvu, Opatija, 2019., str. 313 - 315.

Čl. 3. st. 1. t. 11. Zakona o gradnji.

Čl. 3. st. 1. t. 23. Zakona o gradnji.

Morska obala, kao ex lege pomorsko dobro, proteže se od crte srednjih viših visokih voda mora i obuhvaća pojas kopna koji je ograničen crtom do koje dopiru najveći valovi za vrijeme nevremena kao i onaj dio kopna koji po svojoj prirodi ili namjeni služi korištenju mora za pomorski promet i morski ribolov te za druge svrhe koje su u vezi s korištenjem mora, a koji je širok najmanje šest metara od crte koja je vodoravno udaljena od crte srednjih viših visokih voda, čl. 4. st. 1. ZPDML-a. 
nije moguće sagledati kroz stvarnopravni režim te stoga pridodati im svojstva koja im u spomenutom režimu prirodno pristaju. Riječ je o posebnom pravnom tretmanu koji nastavno na posebno uređenje proklamirano u Ustavu Republike Hrvatske ${ }^{20}$ stavlja nekretnine u statusu pomorskog dobra u zasebnu kategoriju. Pritom valja napomenuti da je pomorsko dobro usamljeno u kategoriji općeg dobra, što sigurno dovodi i do manje posvećenosti pravnoj uređenosti tog područja. S druge strane, kada se govori o problematici legalizacije građevina na pomorskom dobru, navedeno valja razlučiti kroz dvije situacije, prvo predradnje koje valja poduzeti u svrhu gradnje novih građevina na pomorskom dobru i drugo kroz aspekt "ozakonjenja" postojećih nezakonito sagrađenih građevina na pomorskom dobru. Pitanje koje se u oba slučaja postavlja jest tko je uopće ovlašten za pokretanje takvog postupka, odnosno što se smatra dokazom pravnog interesa za navedeno. Da bi se moglo odgovoriti na to pitanje, valja razlučiti je li riječ o građevinama u lučkom ili izvanlučkom području. Predmet ovog rada nije pitanje legalizacije građevina u izvanlučkom području, iako je navedeno pitanje s pravne strane veoma interesantno za daljnju razradu. Predmet ovog rada pitanje je legalizacije građevina u lučkom području, i to lučkom području luka nautičkog turizma. Naime, prema namjeni kojoj služe luke se dijele na luke otvorene za javni promet i luke za posebne namjene. ${ }^{21}$ Luke otvorene za javni promet, pod jednakim uvjetima, može upotrebljavati svaka fizička i pravna osoba sukladno njezinoj namjeni i u granicama raspoloživih kapaciteta, dok su luke posebne namjene u posebnoj upotrebi ili gospodarskom korištenju pravnih ili fizičkih osoba (luka nautičkog turizma, industrijska luka, brodogradilišna luka, ribarska luka i dr.) ili državnog tijela (vojna luka). ${ }^{22}$ Luka nautičkog turizma je poslovno funkcionalna cjelina u kojoj pravna ili fizička osoba posluje i pruža turističke usluge u nautičkom turizmu te druge usluge za potrebe turista (trgovačke, ugostiteljske i dr.). ${ }^{23}$

20 Dalje u tekstu: Ustav RH, Narodne novine, br. 56/1990, 135/1997, 8/1998, 113/2000, 124/2000, 28/2001, 41/2001, 55/2001, 76/2010, 85/2010 i 5/2014. More, morska obala i otoci, vode, zračni prostor, rudno blago i druga prirodna bogatstva, ali i zemljište, šume, biljni i životinjski svijet, drugi dijelovi prirode, nekretnine i stvari od osobitog kulturnoga, povijesnoga, gospodarskog i ekološkog značenja, za koje je zakonom određeno da su od interesa za Republiku Hrvatsku, imaju njezinu osobitu zaštitu. Zakonom se određuje način na koji dobra od interesa za Republiku Hrvatsku mogu upotrebljavati i iskorištavati ovlaštenici prava na njima i vlasnici te naknada za ograničenja kojima su podvrgnuti, čl. 52. Ustava RH.

Čl. 40. st. 1. ZPDML-a.

Čl. 2. st. 1. t. 2. i 3. ZPDML-a.

Čl. 2. st. 1. Pravilnika o kategorizaciji luke nautičkog turizma i razvrstavanju drugih objekata za pružanje usluga veza i smještaja plovnih objekata (Narodne novine, br. 120/2019). 


\section{LEGALIZACIJA GRAĐEVINA U LUKAMA NAUTIČKOG TURIZMA}

Osnovni preduvjet da se utvrdi nalazi li se neka građevina na pomorskom dobru jest da je prethodno utvrđena granica pomorskog dobra. Postojeća pravna regulativa nije idealna i u vezi s time postoje opravdani prigovori u teoriji i praksi. Ipak, ona je osnova za utvrđivanje granice pomorskog dobra te se u stvarnosti odvija relativno sporo. ${ }^{24}$ Situacija s lukama nautičkog turizma ipak je nešto bolja s obzirom na jasno određen obuhvat luke nautičkog turizma iako se i kod njih glede navedenog može javiti njima svojstvena problematika uslijed različitih zakonskih rješenja koja su egzistirala od osamostaljenja do danas. ${ }^{25}$ U slučaju kada nema spora ni problematike oko obuhvata lučkog područja odnosno granice pomorskog dobra u okviru koje se nalazi određena luka nautičkog turizma, tko je ovlašten da poduzme prvi korak ka legalizaciji građevina koje se u njoj nalaze?

\subsection{Tko mogu biti "investitori” za izgradnju građevina u lukama nautičkog turizma?}

Za potrebe izgradnje građevina u zakonskim propisima nailazimo na pojam investitor. No, detaljnijim iščitavanjem Zakona o prostornom uređenju i Zakona o gradnji ne nalazimo točnu definiciju investitora. ${ }^{26}$ Kako je riječ o gradnji,

24 Tako Jug Dujaković, M.; Božić Fredotović, K., Granice vlasničkih ovlaštenja glede nekretnina izgrađenih na morskoj obali Republike Hrvatske, Naše more, vol. 56, br. 3-4, 2009. ., str. 139. O postupku određivanja granica pomorskog dobra vidi više Vladušić, J., Određivanje granica pomorskog dobra u hrvatskom pravu, Zbornik radova Pravnog fakulteta u Splitu, vol. 46, br. 1, 2009., str. 219 - 246. Nakić, J., u doktorskoj disertaciji Određivanje granice pomorskog dobra u Republici Hrvatskoj - de lege lata $i$ de lege ferenda, Pravni fakultet, Split, 2012., na str. 342, navodi da je problem to što u Republici Hrvatskoj nije bilo fiksirano nulto stanje odnosno evidentirana granica pomorskog dobra za cijelu obalu, makar u katastru. Upućujući na Marinković, A., Kritički osvrt na određivanje granica i koncesija pomorskog dobra, Glasilo Hrvatske komore arhitekata i inženjera u gospodarstvu, vol. 4, br. 4, Zagreb, 2004., str. 129, navodi da ubuduće u toj situaciji postoji opasnost da se sve građevine za koje će se sada i pro futuro izdati građevinska dozvola, a nisu u funkcionalnoj vezi s morem, izluče iz pomorskog dobra njegovim sužavanjem pa čak i do crte samog mora i time će se korak po korak ovaj režim urušavati i nestajat će pomorsko dobro na naseljenim dijelovima obale. Tako o navedenoj problematici vidi više Ljubetić, op. cit. u bilj. 16, str. 320 - 328. 
točnije, pitanju legalizacije građevina, možda bi bilo najpogodnije "posuditi" definiciju pojma investitora sadržanu u općim odredbama Zakona o građevinskoj inspekciji ${ }^{27}$, sukladno kojoj je investitor pravna ili fizička osoba u čije ime se gradi ili je izgrađena građevina, odnosno u čije se ime provodi ili je proveden zahvat u prostoru koji nije građenje. ${ }^{28}$ Zakon o gradnji navedenu osobu zapravo definira kroz određenje ${ }^{29}$, što se smatra dokazom pravnog interesa za izdavanje građevinske dozvole. Tako se dokazom pravnog interesa smatra: izvadak iz zemljišne knjige iz kojeg je vidljivo da je investitor vlasnik ili nositelj prava građenja na građevnoj čestici ili građevini na kojoj se namjerava graditi; predugovor, ugovor ili ugovor sklopljen pod uvjetom, na temelju kojeg je investitor stekao ili će steći pravo vlasništva ili pravo građenja; odluka nadležne vlasti na temelju koje je investitor stekao pravo vlasništva ili pravo građenja; ugovor o ortaštvu sklopljen s vlasnikom nekretnine čiji je cilj zajedničko građenje; pisana suglasnost vlasnika zemljišta, odnosno vlasnika postojeće građevine te suglasnost Republike Hrvatske, tijela nadležnog za upravljanje državnom imovinom, za nekretnine kojima Ministarstvo državne imovine upravlja temeljem članka 71. Zakona o upravljanju državnom imovinom ${ }^{30}$; pisana suglasnost fiducijarnog vlasnika dana dotadašnjem vlasniku nekretnine koji je investitor. ${ }^{31}$ Posebne

114/2018) za potrebe primjene navedenog zakona. Tako investitor može biti obiteljsko poljoprivredno gospodarstvo, domaća ili strana pravna osoba registrirana na teritoriju Republike Hrvatske, pravna osoba čiji je osnivač Republika Hrvatska ili jedinica lokalne i područne (regionalne) samouprave, čl. 3. st. 1. t. 6. Zakona o strateškim investicijskim projektima Republike Hrvatske.

Narodne novine, br. 153/2013 i 115/2018.

Čl. 4. st. 2. Zakona o građevinskoj inspekciji.

U čl. 109. Zakona o gradnji.

Narodne novine, br. 52/2018.

Čl. 109. st. 1. Zakona o gradnji. Dokazom pravnog interesa za izdavanje građevinske dozvole u pogledu obuhvata zahvata u prostoru smatra se: izvadak, ugovor, odluka ili suglasnost kojom se dokazuje pravni interes za izgradnju; izvadak iz zemljišne knjige iz kojeg je vidljivo da je investitor nositelj prava služnosti; predugovor, ugovor ili ugovor sklopljen pod uvjetom na temelju kojeg je investitor stekao ili će steći pravo služnosti, zakupa ili korištenja; odluka nadležne državne vlasti na temelju koje je investitor stekao pravo služnosti, čl. 109. st. 2. Zakona o gradnji. Dokazom pravnog interesa za izdavanje građevinske dozvole u navedenim slučajevima smatra se i odluka Vlade Republike Hrvatske o utvrđivanju interesa Republike Hrvatske ili poziv na odredbu posebnog zakona kojom je utvrđen interes Republike Hrvatske za građenje građevine za koju je zatražena građevinska dozvola, ako je investitor podnio zahtjev za izvlaštenje, odnosno ako je investitor podnio zahtjev za rješavanje imovinskopravnih odnosa na zemljištu, građevinama ili drugim nekretninama u vlasništvu Republike Hrvatske, jedinice područne (regionalne) ili lokalne samouprave, čl. 109. 
odredbe predviđene su za nekretnine u statusu općeg dobra, koji status danas u Republici Hrvatskoj ima samo pomorsko dobro. Tako se dokazom pravnog interesa za izdavanje građevinske dozvole u pogledu nekretnine na kojoj stjecanje stvarnih prava nije moguće ili se prema posebnom zakonu pravo građenja stječe koncesijom smatra ugovor o koncesiji kojim se stječe pravo građenja ili drugi akt određen posebnim zakonom, a jedinica lokalne samouprave svoj pravni interes za građenje infrastrukture i jednostavnih građevina na pomorskom dobru dokazuje planom upravljanja pomorskim dobrom za tekuću godinu ili drugim aktom određenim posebnim zakonom. ${ }^{32}$

Iz citirane odredbe možemo razlikovati dvije situacije glede izgradnje građevina na pomorskom dobru. Prva je da za izgradnju građevina na pomorskom dobru investitor može biti koncesionar odnosno pravni subjekt koji posjeduje akt određen posebnim zakonom, a dokaz pravnog interesa je ugovor o koncesiji ili drugi akt određen posebnim zakonom. Valja skrenuti pozornost na to da se kao obvezni sastavni dio odluke o javnom prikupljanju ponuda za dodjelu koncesije ZPDML-om propisuje ${ }^{33}$ izvod iz Detaljnog plana uređenja prostora ili lokacijska dozvola za konkretan zahvat. Također, ovdje se ne smije zaboraviti da se taj isti koncesionar mora po definiranju zahvata u prostoru obratiti davatelju koncesije radi dobivanja suglasnosti na njegovo izvođenje. U drugom slučaju pravni interes odnosno status investitora priznat je i jedinicama lokalne samouprave, ali samo u slučaju građenja infrastrukture i jednostavnih građevina na pomorskom dobru. ${ }^{34}$ Uvodno je već citiran ${ }^{35}$ pojam lučke infrastrukture iz ZPDML-a. Zakon o prostornom uređenju ${ }^{36}$ infrastrukturu općenito definira kao komunalne, prometne, energetske, vodne, pomorske, komunikacijske, elektroničke komunikacijske i druge građevine namijenjene gospodarenju s drugim vrstama stvorenih i prirodnih dobara. Jednostavne su građevine one građevine koje se izvode odnosno grade bez građevinske dozvole ${ }^{37}$, a određene su Pravil-

st. 5. Zakona o gradnji. Dokazom pravnog interesa za izdavanje građevinske dozvole za građenje građevine čije je građenje u interesu Republike Hrvatske na javnoj cesti, nerazvrstanoj cesti, željezničkoj infrastrukturi i javnom vodnom dobru smatra se suglasnost osobe, odnosno tijela koje upravlja tom cestom, infrastrukturom, odnosno javnim vodnim dobrom, čl. 109. st. 6. Zakona o gradnji.

Čl. 109. st. 4. Zakona o gradnji.

Opisana mogućnost za jedinice lokalne samouprave uvedena je novelom Zakona o gradnji od 25. travnja 2019. godine (Narodne novine, br. 39/2019).

35 Vidi supra poglavlje 1.

36 U čl. 3. st. 1. t. 10.

37 Vidi čl. 128. Zakona o gradnji. 
nikom o jednostavnim i drugim građevinama i radovima. ${ }^{38}$ To su primjerice cisterne za vodu, komunalna oprema, privremene građevine za potrebe sajmova i javnih manifestacija i dr. ${ }^{39}$ Iz navedenog slijedi da je koncesionar jedini mogući investitor za izgradnju građevina u kontekstu sadržaja lučke suprastrukture i infrastrukture za luke nautičkog turizma. Također, navedeno znači da je taj isti koncesionar jedini ovlašten za pokretanje postupka ishođenja građevinske i uporabne dozvole za ozakonjenje postojeće suprastrukture i infrastrukture $u$ luci nautičkog turizma. ${ }^{40}$

\subsection{Mogućnost primjene Zakona o postupanju s nezakonito izgrađenim zgradama - stavovi iz prakse}

Dana 13. rujna 2012. godine Ministarstvo graditeljstva i prostornog uređenja dalo je mišljenje ${ }^{41}$ glede moguće primjene Zakona o postupanju s nezakonito izgrađenim zgradama ${ }^{42}$ na ozakonjenje objekata na otocima u kojima nije utvrđena granica pomorskog dobra. U mišljenju je istaknulo da je ZPDML-om uređeno pitanje utvrđivanja granice pomorskog dobra, a Uredbom o postupku utvrđivanja granice pomorskog dobra ${ }^{43}$ propisani su kriteriji i postupak utvrđivanja granica pomorskog dobra. Sukladno odredbama čl. 4. st. 1. ZPDML-a i čl. 3. st. 1. navedene Uredbe, granica pomorskog dobra na morskoj obali obuhvaća pojas kopna koji je širok najmanje šest metara od crte koja je vodoravno udaljena od crte srednjih viših visokih voda. Prema odredbi čl. 6. st. 2. podst. 3. Zakona o postupanju s nezakonito izgrađenim zgradama nezakonito izgrađena zgrada ne može se ozakoniti ako se nalazi na pomorskom dobru. Na temelju navedene odredbe tijelo prvog stupnja donijet će rješenje kojim odbija zahtjev za ozakonjenje ako utvrdi da se zgrada nalazi na pomorskom dobru koje je utvrđeno u postupku provedenom na temelju ZPDML-a i Uredbe o postupku utvrđivanja

38 Narodne novine, br. 112/2017, 34/2018, 36/2019, 98/2019 i 31/2020.

39 Vidi više čl. 2. Pravilnika o jednostavnim i drugim građevinama i radovima.

40 Valja napomenuti da upravo opisano uređenje izgradnje građevina na pomorskom dobru zahtijeva da u izvanlučkom području jedinice lokalne samouprave putem instituta koncesija za posebnu uporabu vrše zahvate u prostoru, koji sadržajno ne pripadaju pod definiciju jednostavnih građevina i infrastrukture. O dosadašnjoj praksi više vidi Ljubetić, op. cit. u bilj. 1, str. 75.

${ }^{4}$ U povodu upita Šibensko-kninska županija, Općina Murter-Kornati, Klasa: 36001/12-02/411, Urbroj: 531-01-12-2, dostupno na: https://www.iusinfo.hr/misljenja-i-tumacenja/MMIN201D20120913N52 (29. listopada 2021.).

42 Narodne novine, br. 86/2012.

43 Narodne novine, br. 8/2004 i 82/2005. 
granice pomorskog dobra. Međutim, u slučajevima kada pomorsko dobro nije utvrđeno prema ZPDML-u i navedenoj Uredbi, činjenicu o tome nalazi li se nezakonito izgrađena zgrada unutar pomorskog dobra ili izvan njega treba utvrditi nadležno upravno tijelo u upravnom postupku izdavanja rješenja o izvedenom stanju, i to primjenom odredaba Zakona o općem upravnom postupku ${ }^{44} \mathrm{o}$ prethodnom pitanju. U tom slučaju ako je evidentno da zgrada, odnosno druga građevina čije se ozakonjenje traži nije na pomorskom dobru, tada će nadležno upravno tijelo samo riješiti prethodno pitanje i, ako su ispunjeni i ostali uvjeti, donijeti rješenje o izvedenom stanju. Međutim, ako se u postupku utvrdi da se nezakonita zgrada odnosno druga građevina nalazi unutar navedenog pojasa ili s tim u vezi postoji sumnja, nadležno upravno tijelo treba prekinuti postupak izdavanja rješenja o izvedenom stanju i uputiti stranku da u određenom roku pokrene postupak za utvrđivanje pomorskog dobra.

U vezi s navedenim mišljenjem javlja se pitanje što ako postoji sumnja o tome je li neka nekretnina na pomorskom dobru, a o tome, kao o prethodnom pitanju, zauzmu različit stav dva različita tijela.

Takva situacija javila se u predmetu koji se vodio pred Visokim trgovačkim sudom Republike Hrvatske, posl.br. Pž 8457/2016-245, gdje je stranka nakon dovršetka parničnog postupka u kojem je utvrđeno da se nekretnina nalazi na pomorskom dobru ishodila rješenje o izvedenom stanju za istu nekretninu sukladno Zakonu o postupanju s nezakonito izgrađenim zgradama. Naime, sud je u postupku kao o prethodnom pitanju riješio da se nekretnina koja je predmet spora nalazi u luci nautičkog turizma pa time ex lege i na pomorskom dobru, dok je upravno tijelo, kao o prethodnom pitanju, utvrdilo da se nekretnina ne nalazi na pomorskom dobru pa stoga i izdalo rješenje o izvedenom stanju. Po podnesenom prijedlogu za ponavljanje parničnog postupka uslijed stjecanja novih dokaza prvostupanjski sud je ocijenio da utvrđenja jesu li predmetne nekretnine sagrađene na pomorskom dobru imaju pravni učinak samo u postupku u kojem je odlučeno o tome kao o prethodnom pitanju sukladno čl. 56. Zakona o općem upravnom postupku i čl. 44. st. 2. Zakona o upravnim sporovima. ${ }^{46}$ Stoga je imajući u vidu navedeno ocijenio da ne bi donio drukčiju presudu od one koju je donio sve da je u prethodno vođenom postupku tuženik mogao koristiti predmetno rješenje (i kasniju presudu Upravnog suda u Splitu) i tuženikov je prijedlog odbio.

44 Narodne novine, br. 47/2009.

45 Rješenje od 20. siječnja 2017., dostupno na https://www.iusinfo.hr/sudska-praksa/ VTSRH2016PzB8457A2 (29. listopada 2021.).

46 Narodne novine, br. 20/2010, 143/2012, 152/2014, 94/2016 i 29/2017. 
Drugostupanjski sud je također potvrdio takav stav prvostupanjskog suda pritom naglasivši da iz obrazloženja upravnog tijela, a kasnije i Upravnog suda, proizlazi da je upravno tijelo u postupku ozakonjenja utvrdilo da u konkretnom slučaju pomorsko dobro nije utvrđeno te je postupilo u smislu odredaba Zakona o općem upravnom postupku koje se odnose na rješavanje prethodnog pitanja i izvršilo očevid na licu mjesta i utvrdilo da građevina čije se ozakonjenje traži nije na pomorskom dobru (unutar pojasa od šest metara) te da na predmetnim česticama u zemljišnim knjigama nije upisano pomorsko dobro. Stoga, prethodno pitanje o kojem se izjasnilo upravno tijelo u obrazloženju rješenja na koje se poziva tuženik ne utječe na status nekretnine kao pomorskog dobra jer je pomorsko dobro određeno po samom zakonu odnosno čl. 3. ZPMDL-a u koje ulaze i luke. Dakle, je li nekretnina pomorsko dobro ili nije, proizlazi iz činjenice može li se ona podvesti pod zakonsku definiciju pomorskog dobra, ovisno o njezinu izgledu, položaju i funkciji u prostoru, dok je rješenje o utvrđivanju granica pomorskog dobra deklaratorno rješenje kojim se utvrđuje da je neka nekretnina pomorsko dobro po samom zakonu.

Tako je i Visoki upravni sud Republike Hrvatske u presudi od 2. ožujka 2016. godine, posl.br. Usž-374/16-2 ${ }^{47}$ utvrdio da nije odlučno to što čestica nije i upisana u zemljišnim knjigama kao pomorsko dobro, već kao javno dobro, već je bitno to što je nesporno riječ o izgrađenoj zgradi na čestici koja se nalazi unutar granica pomorskog dobra prema Uredbi o određivanju granica pomorskog dobra.

Unatoč jasnom stavu sudske prakse razvidno je da u praksi pred upravnim tijelima može doći do ozakonjenja objekata koji se doista i nalaze na pomorskom dobru, na koji način upravna tijela primjenjuju odredbe Zakona o postupanju s nezakonito izgrađenim zgradama na pomorskom dobru. Što učiniti ako nije sigurno nalazi li se nekretnina na pomorskom dobru? Ovdje je zapravo jedino mjerodavno rješenje o utvrđivanju granice pomorskog dobra ishođeno sukladno Uredbi o postupku utvrđivanja granice pomorskog dobra.

\subsection{Ozakonjenje građevina u lukama nautičkog turizma}

Kada se govori o ozakonjenju građevina u lukama nautičkog turizma, prvo valja raščlaniti što bi se uopće imalo smatrati nezakonito izgrađenom građevinom u luci nautičkog turizma. Naime, predmet analize u ovom članku nije mogućnost ozakonjenja građevina sukladno odredbama Zakona o postupanju s nezakonito

47 Dostupno na https://www.iusinfo.hr/sudska-praksa/UpSRH2016UszB374A2 (29. listopada 2021.). 
izgrađenim zgradama $^{48}$, s obzirom na jasno isključenje njegove primjene na pomorsko dobro prema čl. 6. st. 2. predmetnog zakona. ${ }^{49}$ Predmet analize su mogućnosti koje Zakon o prostornom uređenju i Zakon o gradnji pružaju investitoru kada se iz određenog razloga nađe u situaciji da mora ozakoniti postojeće građevine na pomorskom dobru. Zakon o prostornom uređenju normira uvjete planiranja prostora i postupak izdavanja lokacijske dozvole ${ }^{50}$ te sadržava neke specifične odredbe za pomorsko dobro. ${ }^{51} \mathrm{U}$ svrhu normiranja posebne zaštite područja obalnih jedinica lokalne samouprave formira se zaštićeno obalno područje

48 Narodne novine, br. 86/2012, 143/2013, 65/2017 i 14/2019. O legalizaciji nezakonito izgrađenih zgrada kao pokušaju rješavanja problematike bespravne gradnje vidi više u: Sanjković, L.; Kemeter, D., Ozakonjenje nezakonito izgrađenih zgrada u Republici Hrvatskoj, Zbornik radova Međimurskog veleučilišta u Čakovcu, vol. 8, br. 1, 2017, str. 71 - 78 i Britvić Vetma, B.; Stančić Vidrač, E., Postupak ozakonjenja nezakonito izgrađene zgrade, Zbornik radova Veleučilišta u Šibeniku, br. 1-2, 2015., str. 149 - 164. O navedenome više vidi Ljubetić, op. cit. u bilj. 1, str. 72 - 73.

50 Lokacijska dozvola se, među ostalim, izdaje za: zahvate u prostoru koji se prema posebnim propisima kojima se uređuje gradnja ne smatraju građenjem, etapno i/ili fazno građenje građevine, složeni zahvat u prostoru, građenje na zemljištu, odnosno građevini za koje investitor nije riješio imovinskopravne odnose ili za koje je potrebno provesti postupak izvlaštenja te građenje građevina ako to stranka zatraži, čl. 125. Zakona o prostornom uređenju.

51 Prostorno planiranje morskog područja definirano je kao proces prostornog planiranja u kojem subjekti prostornog uređenja analiziraju i organiziraju ljudske aktivnosti na morskom području radi ostvarivanja ekoloških, gospodarskih i socijalnih ciljeva. Čl. 3. st. 1. t. 30. Zakona o prostornom uređenju. Morsko područje su unutarnje morske vode Republike Hrvatske, teritorijalno more Republike Hrvatske, zračni prostor iznad njih te dno i podzemlje tih morskih prostora, zaštićeni ekološko-ribolovni pojas Republike Hrvatske i epikontinentalni pojas Republike Hrvatske, a u smislu pripadnosti morskoj regiji pripada morskoj regiji Sredozemno more, podregija Jadransko more, čl. 3. st. 1. t. 21. Zakona o prostornom uređenju. Morsko područje se planira: Državnim planom prostornog razvoja, Prostornim planom zaštićenog ekološkog i ribolovnog područja, Prostornim planom epikontinentalnog pojasa Republike Hrvatske, prostornim planovima nacionalnih parkova i parkova prirode koji obuhvaćaju morsko područje, prostornim planovima županija koje obuhvaćaju morsko područje i prostornim planovima uređenja gradova, odnosno općina, unutar njihovih granica određenih sukladno posebnim propisima i prikazanim u Registru prostornih jedinica koji se vodi na temelju posebnih propisa kojima se uređuje državna izmjera i katastar nekretnina te generalnim urbanističkim planovima i urbanističkim planovima uređenja koji obuhvaćaju morsko područje. Zahvati u prostoru i površine državnog značaja i područnog (regionalnog) značaja koji se mogu planirati na morskom području određuju se uredbom iz članka 56. stavka 2. Zakona o prostornom uređenju, a zahvati u prostoru i površine koje se mogu planirati na morskom području prostornim planovima lokalne razine odre- 
mora kao područje od posebnog interesa za Republiku Hrvatsku. Planiranje i korištenje prostora zaštićenog obalnog područja se radi zaštite, ostvarenja ciljeva održivog, svrhovitog i gospodarski učinkovitog razvoja provodi uz ograničenja u pojasu kopna i otoka u širini od $1000 \mathrm{~m}$ od obalne crte i pojasu mora u širini od $300 \mathrm{~m}$ od obalne crte (tzv. prostor ograničenja). ${ }^{52}$ Pojedini autori ${ }^{53}$ upozoravaju da se u praksi ponekad miješaju pojmovi “pomorsko dobro" i “zaštićeno obalno područje" kao da je riječ o istom dijelu teritorija. No, navedeno nisu isti pojmovi, niti je isti teritorij, osim u dijelu uz more gdje se preklapaju zona pomorskog dobra i dio zaštićenog obalnog područja uz more. Pri regulaciji ${ }^{54}$ mogućih zahvata na pomorskom dobru jasno je da je mogućnost izgradnje novih građevina znatno

đuju se pravilnikom iz članka 56. stavka 3. Zakona o prostornom uređenju, čl. 49a. Zakona o prostornom uređenju.

52 Čl. 45. st. 1. - 3. Zakona o prostornom uređenju. U zaštićenom obalnom području prostornim planiranjem mora se: očuvati i sanirati ugrožena područja prirodnih, kulturno-povijesnih i tradicijskih vrijednosti obalnog i zaobalnog krajolika te poticati prirodnu obnovu šuma i autohtone vegetacije, odrediti mjere zaštite okoliša na kopnu i u moru te osobito zaštititi resurse pitke vode, osigurati slobodan pristup obali, prolaz uz obalu te javni interes u korištenju, pomorskog dobra, očuvati nenaseljene otoke i otočiće prvenstveno za poljoprivredne djelatnosti, rekreaciju, organizirano posjećivanje, istraživanje i bez formiranja građevinskih područja, uvjetovati razvitak infrastrukture zaštitom i očuvanjem vrijednosti krajolika, ograničiti međusobno povezivanje i dužobalno proširenje postojećih građevinskih područja, odnosno nova građevinska područja planirati izvan površina koje su u naravi šume te sanirati napuštena eksploatacijska polja mineralnih sirovina i proizvodna područja prvenstveno pejzažnom rekultivacijom ili ugostiteljsko-turističkom i sportsko-rekreacijskom namjenom, čl. 46. Zakona o prostornom uređenju. O određivanju građevinskih područja u prostoru ograničenja, mogućim zahvatima u prostoru ograničenja kao i planiranju ugostiteljsko-turističke i sportske namjene te planiranju morskog područja vidi čl. 47. - 49f. Zakona o prostornom uređenju.

53 Tako Frković, S., Nekretnine na pomorskom dobru i otocima, izlaganje s 13. Foruma poslovanja nekretninama, HGK, Rovinj, 2008., str. 13.

54 Valja napomenuti da Zakon o prostornom uređenju izričito ne normira tko može biti podnositelj zahtjeva za lokacijsku dozvolu, već samo određuje tko su sve stranke u postupku izdavanja lokacijske dozvole, pa je stoga navedeno potrebno iščitati iz odredaba Zakona o gradnji i pratećih podzakonskih propisa. Naime, stranka u postupku lokacijske dozvole je podnositelj zahtjeva, vlasnik nekretnine za koju se izdaje lokacijska dozvola i nositelj drugih stvarnih prava na toj nekretnini te vlasnik i nositelj drugih stvarnih prava na nekretnini koja neposredno graniči s nekretninom za koju se izdaje lokacijska dozvola. Iznimno od navedenog, stranka $\mathrm{u}$ postupku lokacijske dozvole za provedbu zahvata u prostoru koji je od interesa za Republiku Hrvatsku ili koju izdaje Ministarstvo su podnositelj zahtjeva, vlasnik nekretnine za koju se izdaje lokacijska dozvola i nositelj drugih stvarnih prava na toj nekretnini, čl. 141. st. 1. i 2. Zakona o prostornom uređenju. 
ograničenija od postojeće situacije na koju nailazimo na hrvatskoj obali. Bilo bi opravdano reći da je to nastavak tendencije da se umanji intenzivna gradnja smještajnih objekata koja bi mogla ugroziti prirodne i kulturne vrijednosti prostora. Stoga, prostorno planiranje u navedenome igra ključnu ulogu utjecajem na namjenu te režime korištenja prostora. ${ }^{55}$ Zakon o gradnji uređuje postupak izdavanja građevinske i uporabne dozvole te projektiranje i građenje građevina.

Sve navedene dozvole uvjet su zakonitosti izgrađene građevine kako općenito tako i u lukama nautičkog turizma. Znači li to da građevina nije zakonita ako joj nedostaje bilo koja od navedenih dozvola? Na to se pitanje ne može jednoznačno odgovoriti jer građevine datiraju iz različitih razdoblja zakonodavnog uređenja na ovim prostorima. Kako bi doskočio tom problemu, zakonodavac je u Zakonu o gradnji unio određene presumpcije glede građevina s obzirom na vrijeme njihove izgradnje. Tako se navedeni zakon referira na tri pojma: akt za uporabu građevine, akt za ozakonjenje te akt kojima se nezakonito izgrađena građevina izjednačava sa zakonito izgrađenom građevinom. Akt za uporabu građevine u smislu Zakona o gradnji je svaki akt za uporabu građevine, akt kojim je građevina ozakonjena te akt, odnosno dokument kojim se nezakonito izgrađena građevina izjednačava sa zakonito izgrađenom građevinom, izdan, odnosno pribavljen na temelju prije važećeg zakona. Akti za uporabu građevine su uporabna dozvola, potvrda upravnog tijela da mu je dostavljeno završno izvješće nadzornog inženjera, uvjerenje za uporabu, pravomoćna građevinska dozvola, odnosno drugi odgovarajući akt izdan do 19. lipnja 1991. s potvrdom građevinske inspekcije da nije u tijeku postupak građevinske inspekcije i dozvola za upotrebu. ${ }^{56}$ Akti za ozakonjenje su rješenje o izvedenom stanju i potvrda izvedenog stanja. ${ }^{57}$ Akti kojima se nezakonito izgrađena građevina izjednačava sa zakonito izgrađenom građevinom su uvjerenje katastarskog ureda, odnosno Središnjeg ureda Državne geodetske uprave da je zgrada evidentirana do 15. veljače 1968. i uvjerenje upravnog tijela da je zgrada izgrađena do 15 . veljače $1968 .{ }^{58}$ Je li u biti riječ o istom aktu? Ne, jer svaki akt regulira drukčiju zatečenu pravnu situaciju. No

55 Vidi Paunović, A., Uloga turističkih subjekata u izgradnji struktura za povremeno stanovanje (hoteli, marine, kampovi), u: Kuća pokraj mora: povremeno stanovanje na hrvatskoj obali, knjiga 31., Institut društvenih znanosti "Ivo Pilar" i Ministarstvo zaštite okoliša, prostornog uređenja i graditeljstva Republike Hrvatske, Zagreb, 2006., str. 137 - 154. Čl. 175. st. 1. i 2. Zakona o gradnji. građenom građevinom su dokumenti iz članka 332. stavaka 1., 2. i 3. Zakona o prostornom uređenju i gradnji (Narodne novine, br. 76/2007, 38/2009, 55/2011, 90/2011, 50/2012 i 55/2012), čl. 175. st. 4. i 5. Zakona o gradnji. 
sve tri vrste akata imaju isti pravni doseg što se tiče činjenice "zakonitosti" građevine i mogućnosti evidentiranja građevine u katastru i zemljišnoj knjizi. ${ }^{59}$

A što ako investitor ne može ozakoniti građevinu na temelju neke od navedenih pravnih osnova? U slučaju u kojem prema citiranim odredbama Zakona o gradnji nije moguće ishoditi potreban akt, treba pretpostaviti da će investitor pokušati nelegalni status građevine rješavati pribavom sljedeće dozvole u nizu koja mu nedostaje.

S obzirom na načelo zabrane retroaktivnosti propisa, odredbe Zakona o prostornom uređenju i Zakona o gradnji čak i u prekršajnom dijelu reguliraju samo buduće situacije. ${ }^{60}$ Nesporno je da danas diljem jadranske obale i dalje postoje građevine bez zakonom propisanih dozvola. Inspekcijski nadzor građenja, provedbe stručnog nadzora građenja, održavanja i uporabe građevina u nadležnosti je građevinske inspekcije. ${ }^{61}$ Zbog brojnosti objekata na jadranskoj obali unatoč

59 Vidi čl. 148., 148a. i 149. Zakona o gradnji. Tako je u predmetu Klasa: 360-01/1402/55, Ur.broj: 531-01-14-2, Ministarstvo graditeljstva i prostornog uređenja 4. veljače 2014. godine dalo mišljenje na upit može li katastarski ured i nadležni sud nakon stupanja na snagu važećeg Zakona o gradnji evidentirati izgrađenu građevinu za koju je ranije pribavljen neki od dokumenata iz članka 175. Zakona o gradnji, koji se u skladu s čl. 175. st. 6. smatraju uporabnom dozvolom. U mišljenju je istaknuto kako je odredbom čl. 148. st. 1. Zakona o gradnji propisano da katastarski ured evidentira građevinu u katastru ako je za tu građevinu izdana uporabna dozvola, dok je odredbom čl. 149. st. 1. istoga Zakona propisano da nadležni sud prilikom upisa građevine u zemljišnu knjigu po službenoj dužnosti u posjedovnici zemljišne knjige stavlja zabilježbu da je za evidentiranje građevine u katastru priložena uporabna dozvola te pri tome navodi tijelo graditeljstva koje je dozvolu izdalo te njezinu klasu, urudžbeni broj i datum izdavanja. Odredbom, pak, čl. 175. st. 6. propisano je da se uporabnom dozvolom u smislu Zakona o gradnji smatraju i akti za uporabu građevine, akti za ozakonjenje, akti kojima se nezakonito izgrađena građevina izjednačava sa zakonito izgrađenom građevinom te dokumenti kojima se nezakonito izgrađena građevina izjednačava sa zakonito izgrađenom građevinom, koji su izdani odnosno pribavljeni na temelju Zakona koji je bio na snazi prije stupanja na snagu Zakona o gradnji. Dakle, katastarski ured i nadležni sud evidentiraju građevinu u katastru odnosno zemljišne knjige te u posjedovnici zemljišne knjige stavljaju zabilježbu da je za evidentiranje građevine u katastru priložena uporabna dozvola na temelju uporabne dozvole, odnosno nekog od akata ili dokumenata iz odredbe članka 175. stavka 1. Zakona o gradnji, dostupno na: https://www.iusinfo. hr/misljenja-i-tumacenja/MMIN201D20140204N128 (29. listopada 2021.).

60 Tako, primjerice, sankcije zbog uporabe građevine bez uporabne dozvole, vidi čl. 162. st. 2. t. 13. Zakona o gradnji.

${ }_{61}$ Čl. 2. st. 2. Zakona o građevinskoj inspekciji. 
akcijama $^{62}$ koje provodi građevinska inspekcija uz postupanje po eventualnim prijavama i dalje je moguće zateći objekte koji su pukom slučajnosti ostali neevidentirani u svojem "nelegalnom" statusu. Navedenome doprinosi i činjenica da se pojedini objekti ne nalaze u ex lege pojasu pomorskog dobra, već u širem pojasu u obuhvatu pomorskog dobra, što doprinosi njihovoj manjoj vidljivosti. U nekim slučajevima će investitori uspjeti pribaviti potrebne dozvole prije nego što uopće dođe do inspekcijskog nadzora ili prijave. Inače, Zakon o građevinskoj inspekciji pod pojmom nelegalne građevine tretira sve one koje ne posjeduju izvršnu građevinsku dozvole ili glavni projekt odnosno drugi akt. ${ }^{63}$ Što ako građevina posjeduje neki od navedenih akata? Je li to dovoljno? Naime, prema postojećem uređenju izgrađena građevina, odnosno rekonstruirana građevina može se početi koristiti, odnosno staviti u pogon te se može donijeti rješenje za obavljanje djelatnosti u toj građevini prema posebnom zakonu, nakon što se za tu građevinu izda uporabna dozvola. ${ }^{64} \mathrm{U}$ toj situaciji zahtjev za izdavanje uporabne dozvole podnosi investitor, odnosno vlasnik građevine ${ }^{65}$ te zahtjevu prilaže fotokopiju građevinske dozvole, odnosno primjerak glavnog projekta za građevinu koja se može graditi ili radove koji se mogu izvoditi bez građevinske dozvole na temelju glavnog projekta; podatke o sudionicima u gradnji; pisanu izjavu izvođača o izvedenim radovima i uvjetima održavanja građevine; završno izvješće nadzornog inženjera o izvedbi građevine; izjavu ovlaštenog inženjera geodezije da je građevina smještena na građevnoj čestici, odnosno unutar obuhvata zahvata u prostoru u skladu s građevinskom dozvolom, odnosno glavnim projektom; geodetsku snimku izvedenog stanja građevine ili geodetski elaborat i/ili drugi akt određen posebnim propisima na temelju kojega se u katastru, odnosno katastru infrastrukture i zemljišnoj knjizi evidentiraju zgrade, druge građevine, odnosno način korištenja zemljišta s podacima o lomnim točkama građevine, građevne čestice, odnosno obuhvata zahvata u prostoru prikazane u GML formatu u elektroničkom obliku; dokaz da je u katastru formirana građevna čestica, ako je riječ o građevini za koju se lokacijskom dozvolom određuje

62 Od većih se mogu istaknuti akcija krajem listopada i početkom studenog 2017. godine kada su uklonjene 33 nezakonito izgrađene građevine na pomorskom dobru - Žnjanski plato u Splitu. Također, tijekom 2018. godine uklanjale su se bespravne gradnje u Istri, točnije objekti većinom građeni na području općine Vodnjan u naselju Peroj, dostupno na https://mpgi.gov.hr/vijesti-8/uklanja-se-bespravna-gradnja-na-podrucju-splitsko-dalmatinske-zupanije/7313 (29. listopada 2021.).

Vidi čl. 30. Zakona o građevinskoj inspekciji.

Stranka u postupku izdavanja uporabne dozvole je investitor, odnosno vlasnik građevine na čiji je zahtjev pokrenut postupak izdavanja te dozvole, čl. 138. Zakona o gradnji. 
obuhvat zahvata u prostoru unutar kojega se parcelacijskim elaboratom formira građevna čestica, osim za izdavanje privremene uporabne dozvole i energetski certifikat zgrade, ako se zahtjev podnosi za zgradu koja mora ispunjavati zahtjeve energetske učinkovitosti. ${ }^{66}$ Uporabna dozvola za građevinu izgrađenu na temelju građevinske dozvole odnosno bez građevinske dozvole na osnovi glavnog projekta izdaje se u roku od osam dana od obavljenog tehničkog pregleda ako se utvrdi ispunjenje zakonom propisanih uvjeta. ${ }^{67}$

A što ako se pri provedbi inspekcijskog nadzora utvrdi da zgrada nema ni Zakonom o građevinskoj inspekciji propisani minimum za potvrdu legalnosti statusa?

\subsubsection{Pravne posljedice nezakonitosti građevina u lukama nautičkog turizma}

Ako se pri provedbi inspekcijskog nadzora utvrdi da je riječ o građevini koja se gradi ili je izgrađena bez izvršne građevinske dozvole ili bez glavnog projekta odnosno drugog akta te ako tijekom građenja utvrdi neotklonjive nepravilnosti zbog kojih je ugrožena stabilnost građevine, stabilnost okolnih građevina, stabilnost tla ili je na drugi način ugrožen život ljudi, kao i u drugim zakonom propisanim slučajevima ${ }^{68}$, građevinski inspektor rješenjem naređuje investitoru odnosno vlasniku uklanjanje u određenom roku građevine, odnosno njezina

66 Čl. 137. st. 1. i 2. Zakona o gradnji.

${ }^{67}$ Za građevinu izgrađenu na temelju građevinske dozvole mora se utvrditi: da je uz zahtjev za njezino izdavanje priložena propisana dokumentacija, da je građevina izgrađena u skladu s građevinskom dozvolom, u pogledu ispunjavanja temeljnih zahtjeva za građevinu, lokacijskih uvjeta i drugih uvjeta određenih građevinskom dozvolom, da je građevina priključena na prometnu površinu i druge građevine i uređaje komunalne ili druge infrastrukture određene građevinskom dozvolom i da su privremene građevine izgrađene $\mathrm{u}$ okviru pripremnih radova, oprema gradilišta, neutrošeni građevinski i drugi materijal, otpad i sl. uklonjeni, a zemljište na području gradilišta i na prilazu gradilišta dovedeno u uredno stanje. Za građevinu izgrađenu bez građevinske dozvole na temelju glavnog projekta ako se utvrdi: da je uz zahtjev za njezino izdavanje priložena propisana dokumentacija, da je građevina izgrađena u skladu s glavnim projektom u pogledu ispunjavanja temeljnih zahtjeva za građevinu, lokacijskih uvjeta i drugih uvjeta određenih glavnim projektom i građevina svojom namjenom, smještajem i vanjskim mjerama svih nadzemnih i podzemnih dijelova nije protivna prostornom planu u vrijeme izrade glavnog projekta, čl. 144. st. 1. i 2. Zakona o gradnji.

68 Vidi čl. 30. st. 4. i 5. Zakona o građevinskoj inspekciji. 
dijela. ${ }^{69}$ Naravno, ako je građenje u tijeku, građevinski inspektor naređuje investitoru, odnosno vlasniku građevine i mjeru obustave građenja. ${ }^{70}$ Ako se investitor, odnosno vlasnik građevine ne može utvrditi, rješenje o uklanjanju građevine i obustavi građenja donosi se protiv nepoznate osobe. ${ }^{71}$ Protiv rješenja koje donosi građevinski inspektor ne može se izjaviti žalba, ali se može pokrenuti upravni spor. ${ }^{72}$ Rješenje o uklanjanju građevine, odnosno njezina dijela izvršava se putem treće osobe na odgovornost stranke kojoj je inspekcijskim rješenjem naređeno uklanjanje. Rok u kojem je izvršenik obvezan postupiti po rješenju ne može biti kraći od devedeset dana, a prije pristupanja izvršenju rješenja putem treće osobe izvršenika se na izvršenje prisiljava izricanjem šest novčanih kazni. ${ }^{73}$

Iz navedenog pregleda postojeće regulative slijedi da bi koncesionar luke nautičkog turizma u situaciji u kojoj ne posjeduje izvršnu građevinsku dozvolu ni glavni projekt, a nije riječ o objektu glede kojeg se može primijeniti presumpcija iz čl. 175. Zakona o gradnji, taj objekt morao ukloniti jer će se u protivnom po eventualnom donošenju rješenja građevinske inspekcije ukloniti putem treće osobe, na njegov trošak.

Navedena nemogućnost legalizacije građevine ima za posljedicu nemogućnost ishođenja uporabne dozvole za luku nautičkog turizma, koja je pak preduvjet obavljanju djelatnosti nautičkog turizma sukladno Zakonu o pružanju usluga u turizmu ${ }^{74}$ i Pravilniku o kategorizaciji luke nautičkog turizma i razvrstavanju drugih objekata za pružanje usluga veza i smještaja plovnih objekata. ${ }^{75}$

69 Čl. 30. st. 1. t. 1. - 3. Zakona o građevinskoj inspekciji. Iznimno, građevinski inspektor neće narediti uklanjanje građevine ili njezina dijela (potporni zidovi, podzemne građevine $\mathrm{u}$ neposrednoj blizini drugih građevina i sl.) ako bi tim uklanjanjem nastala opasnost za život ljudi, druge građevine ili stabilnost tla na okolnom zemljištu, nego će takvu građevinu označiti opasnom do usklađenja s propisima koji uređuju gradnju, čl. 30. st. 1. t. 4. Zakona o građevinskoj inspekciji.

70 Čl. 30. st. 2. Zakona o građevinskoj inspekciji.

71 Čl. 19. st. 2. Zakona o građevinskoj inspekciji. Ako je stranka u postupku inspekcijskog nadzora nepoznata ili nepoznatog boravišta, rješenje odnosno zaključak dostavlja se stavljanjem na oglasnu ploču nadležnog ministarstva, područnog ureda, odnosno područne jedinice. Obavijest o tome ostavlja se na gradilištu, odnosno građevini i objavljuje na mrežnim stranicama nadležnog ministarstva, čl. 20. st. 1. Zakona o građevinskoj inspekciji.

72 Čl. 22. st. 1. Zakona o građevinskoj inspekciji.

73 Vidi čl. 31., 32. i 38. Zakona o građevinskoj inspekciji.

74 Narodne novine, br. 130/2017, 25/2019, 98/2019 i 42/2020. Vidi čl. 86. Zakona o pružanju usluga u turizmu.

75 Narodne novine, br. 120/2019. 


\subsubsection{Ekonomske posljedice nezakonitosti građevina u lukama nautičkog turizma}

Nesporno je da izgrađena luka nautičkog turizma za koju se ne može ishoditi potrebna dozvola za rad predstavlja neiskorišteni kapital. Na navedeno se već godinama upućuje ne samo u praksi već i u doktrini. S te strane ni ZPDML nije ponudio puno bolje uređenje od PZ-a, za koji je utvrđeno ${ }^{76}$ da je pokušavajući ostvariti dva cilja - osigurati zaštitu pomorskog dobra kao stvari na uporabi svih i istodobno omogućiti uspješno gospodarsko iskorištavanje pomorskog dobra ostao negdje "na pola puta", sadržavajući međusobno proturječne odredbe koje nisu u praksi polučile zadovoljavajuće rezultate. Navedeno vrijedi tim više što upravo postupak legalizacije nezakonito izgrađenih objekata pruža osnovu za početak pravilnog razvoja odnosno planskog građenja. ${ }^{77}$ Građevine koje se ne mogu iskorištavati zbog nedostatka dozvole ne mogu donijeti ni prihode ni radna mjesta, što se sve posljedično ogleda i u manjim prihodima za državni proračun.

U tom smjeru nužnim se pokazuje izrada nove regulative koja će dati odgovarajući poticaj iskorištavanju gospodarskog potencijala pomorskog dobra, uzimajući u obzir potrebu njegova dugoročnog očuvanja.

\section{NOVI SMJEROVI U RAZVOJU REGULATIVE OZAKONJENJA GRAĐEVINA NA POMORSKOM DOBRU}

\subsection{Prijedlog Zakona o postupanju s nezakonito izgrađenim infrastrukturnim građevinama}

Zadnji pokušaj ozakonjenja nezakonito izgrađenih objekata, kojim bi se obuhvatili i objekti izgrađeni na pomorskom dobru, bio je Prijedlog zakona o postupanju s nezakonito izgrađenim infrastrukturnim građevinama. ${ }^{78}$ Iako

76 Tako Marin, J., Koncesija i pravo vlasništva na objektima izgrađenima na pomorskom dobru, Pravo u gospodarstvu, vol. 37, 1998., str. 246. O neprikladnosti modela sadašnjeg upravljanja pomorskim dobrom više vidi Vuković, A.; Luković, T., Maritime domain as public property, the results of strategic planing of national economy development, or?, DIEM - Dubrovnik International Economic Meeting, University of Dubrovnik, vol. 3, br. 1, 2017., str. $346-360$.

77 Tomić, J., Legalizacija nezakonito izgrađenih zgrada, Tehnički glasnik, vol. 9, br. 2, 2015. str. 197.

78 Dalje u tekstu: Prijedlog zakona. Predsjedniku Hrvatskoga sabora podnio ga je Klub zastupnika GLAS-a u Hrvatskome saboru, aktom od 29. studenoga 2019. godine, vidi 16. sjednicu 9. saziva Hrvatskog sabora, dostupno na: https://www.sabor. $\mathrm{hr} / \mathrm{hr} /$ sjednice/pregled-dnevnih-redova (29. listopada 2021.). 
Prijedlog zakona sadržava nekoliko odredaba koje se tiču legalizacije objekata na pomorskom dobru, kao što mu i sam naziv kaže, riječ je o infrastrukturnim građevinama. Kako ZPDML glede suprastukture upotrebljava naziv građevine, a infrastrukture objekti, dok Zakon o gradnji definira samo pojam građevine kao predmeta uređenja, postavlja se pitanje što bi točno činilo sadržaj pojma infrastrukturnih građevina prema Prijedlogu zakona. Infrastrukturna građevina definira se kao linijska infrastrukturna građevina, vodna građevina, prometna površina i željeznička infrastruktura sastavljena od cijevi, kabela, zdenaca. Linijska infrastrukturna građevina je pak sastavljena od cijevi, kabela, zdenaca (revizijskih okana), kabineta i drugih prostora za smještaj opreme, prepumpnih i mjernih stanica i drugih pripadajućih elemenata koji čine jedinstvenu i nedjeljivu funkcionalnu tehničko-tehnološku cjelinu koja omogućava prijenos signala, tvari, električne energije, elektroničkih komunikacijskih signala, vode, otpadnih i oborinskih voda (kanalizacija), toplinske energije (toplovodi), plina, nafte i naftnih produkata. ${ }^{79}$ Vodna se građevina pak definira kao građevina ili skupovi građevina zajedno s pripadajućim uređajima i opremom, koji čine tehničku, odnosno tehnološku cjelinu, a služe za uređenje vodotoka i drugih površinskih voda, za zaštitu od štetnog djelovanja voda, za zahvaćanje voda u cilju njihova namjenskog korištenja i za zaštitu voda od onečišćenja ${ }^{80}$ Dakle, primjerice, kod vodnih građevina riječ je definiciji građevina koja bi se mogla u manjem dijelu podudarati sa definicijom lučke suprastrukture. Je li navedeno bio cilj podnositelja Prijedloga zakona, upravo zbog razlike u izloženim definicijama iz različitih zakona, nije posve jasno.

Prijedlogom zakona propisano je da se može ozakoniti nezakonito izgrađena infrastrukturna građevina, koja je vidljiva na digitalnoj ortofoto karti Državne geodetske uprave izrađenoj na temelju aerofotogrametrijskog snimanja do stupanja na snagu navedenog zakona ili je do tog dana evidentirana na katastarskom planu ili drugoj službenoj kartografskoj podlozi, o čemu tijelo nadležno za državnu izmjeru i katastar nekretnina na zahtjev stranke izdaje uvjerenje odnosno za koju vlasnik, odnosno upravitelj može dostaviti snimke izvedenog stanja, geodetski elaborat o izvedenom stanju ili druge dokaze da je infrastrukturna građevina izgrađena prije stupanja na snagu navedenog zakona. ${ }^{81} \mathrm{No}$, propisana su i određena ograničenja glede mogućnosti ozakonjenja. Tako se, primjerice, nezakonito izgrađena infrastrukturna građevina ne može ozakoniti ako se nalazi unutar nacionalnog parka, parka prirode te područja zaštićenih

\footnotetext{
79 Čl. 3. st. 2. t. 7. i 13. Prijedloga zakona.

80 Čl. 3. st. 2. t. 23. Prijedloga zakona.

81 Čl. 7. st. 1. i 2. Prijedloga zakona.
} 
u kategorijama strogi rezervat, posebni rezervat, spomenik prirode i spomenik parkovne arhitekture, osim uz suglasnost ministarstva nadležnog za zaštitu prirode i dijelova prirode. Nezakonito izgrađena infrastrukturna građevina ne može se ozakoniti ako se nalazi na pomorskom dobru, osim uz suglasnost tijela koje temeljem posebnog propisa upravlja i vodi brigu o zaštiti pomorskog dobra. ${ }^{82}$ Iz citirane regulacije ostaju otvorena sljedeća pitanja. Koje bi se tijelo po pitanju pomorskog dobra imalo smatrati kao nadležno javnopravno tijelo za davanje suglasnosti za ozakonjenje nezakonito izgrađene i nezakonito rekonstruirane infrastrukture? U situaciji da se određena infrastrukturna građevina nalazi na nekretnini koja se smatra pomorskim dobrom i dijelom nacionalnog parka, bi li se u tom slučaju tražila suglasnost dvaju nadležnih javnopravnih tijela ili bi jedno od tih dvaju tijela imalo primat pri primjeni zakona. Prijedlogom zakona propisano je da se predmetna suglasnost nadležnog tijela može izdati ako nezakonito izgrađena infrastrukturna građevina nije izgrađena protivno uvjetima korištenja pomorskog dobra prema posebnim propisima o pomorskom dobru. ${ }^{83}$ Znači li navedeno da bi svako korištenje pomorskog dobra koje je rezultiralo izgradnjom infrastrukturne građevine, a koje nije bilo u skladu sa zakonom imalo za posljedicu nemogućnost ozakonjenja takve građevine? Primjerice, ako bi netko izgradio građevinu čija izgradnja nije bila predviđena za vrijeme trajanja nekog koncesijskog odnosa od strane davatelja koncesije. Što se tiče samog postupka, nezakonito izgrađena infrastrukturna građevina ozakonjuje se rješenjem o izvedenom stanju. ${ }^{84}$

Prijedlogom zakona predviđen je prekluzivni rok od dvije godine za podnošenje zahtjeva ${ }^{85}$ tijelu koje bi inače bilo nadležno za izdavanje građevinske dozvole za tu vrstu infrastrukturne građevine. ${ }^{86}$ Ovlaštenici na podnošenje zahtjeva su vlasnik i upravitelj infrastrukturne građevine. ${ }^{87}$ Upravitelj infrastrukturne građevine svoje svojstvo dokazuje sukladno odredbama posebnih propisa. ${ }^{88}$ Bi li se za pomorsko dobro navedeno imalo tumačiti sukladno odredbama

82 Čl. 8. st. 1. i 3. Prijedloga zakona.

83 Čl. 9. st. 4. Prijedloga zakona.

84 Čl. 10. st. 1. Prijedloga zakona.

85 Čl. 12. st. 2. Prijedloga zakona.

86 Sukladno propisima iz područja gradnje to mogu biti Ministarstvo graditeljstva i prostornog uređenja, upravno tijelo velikoga grada, Grada Zagreba i županije nadležno za upravne poslove graditeljstva, čl. 10. st. 2. Prijedloga zakona.

87 Čl. 12. st. 1. Prijedloga zakona.

88 Vidi čl. 14. Prijedloga zakona. 
ZPDML-a ili odredbama Zakona o gradnji? Niz je tako neodgovorenih pitanja glede konkretnog prijedloga.

Dana 12. ožujka 2020. godine na 211. sjednici Vlada Republike Hrvatske dala je mišljenje ${ }^{89}$ Hrvatskomu saboru da ne prihvati Prijedlog zakona, obrazlažući da predmetnim Prijedlogom nisu u potpunosti definirane pravne posljedice ozakonjenja i utjecaj na prostorno planiranje s obzirom na način rješavanja imovinskopravnih i drugih odnosa i neusklađenost stvarnog stanja s podacima katastra i gruntovnice samih infrastrukturnih građevina, odnosno nekretnina na kojima se one nalaze. Složenost predmetnog usklađivanja čini i primjena različitih pravnih režima za pojedine vrste infrastrukturnih građevina što je, među ostalim, i dovelo do nezakonite izgradnje infrastrukturnih građevina. Nadalje, procjenjuje da će za provedbu postupka ozakonjenja infrastrukturnih građevina koje su u vlasništvu Republike Hrvatske biti potrebno osigurati određena financijska sredstva u državnom proračunu Republike Hrvatske za izradu dokumentacije koja je potrebna za izdavanje rješenja o izvedenom stanju, što je predlagatelj propustio procijeniti. Također, ističe da o predmetnom Prijedlogu zakona nije provedena šira javna rasprava sa svim dionicima sustava te da rješenja iznesena u Prijedlogu zakona ne ispunjavaju svoju svrhu. Osim toga, Vlada Republike Hrvatske napominje da je u tijeku priprema propisa kojim će se regulirati postupanje s nezakonito izgrađenim infrastrukturnim građevinama, a njegovo upućivanje $\mathrm{u}$ daljnju proceduru će uslijediti nakon provedenih stručnih analiza i javne rasprave.

\subsection{Novi pokušaj uređenja pitanja nezakonito izgrađene infrastrukture}

Dana 27. kolovoza 2021. godine na Središnjem portalu za savjetovanja s javnošću (e-Savjetovanja) objavljen je Obrazac prethodne procjene za Zakon o postupanju s nezakonito izgrađenom infrastrukturom. ${ }^{90}$ Kao cilj koji se namjerava postići tim nacrtom prijedloga zakona navodi se ozakonjenje nezakonito izgrađene i nezakonito rekonstruirane infrastrukture u smislu upravnih propisa kojima se uređuje upravno područje prostornog uređenja i gradnje radi njihova uključivanja u pravni promet kao zakonito izgrađenih građevina, što će omogućiti njihovu rekonstrukciju, stavljanje u rad u određenim slučajevima i omogućit

89 Dostupno na: https://vlada.gov.hr/sjednice/211-sjednica-vlade-republike-hrvatske28966/28966 (29. listopada 2021.).

90 Stručni nositelj je Ministarstvo prostornoga uređenja, graditeljstva i državne imovine, obrazac je dostupan na: https://esavjetovanja.gov.hr/ECon/MainScreen?entityId=17378 (29. listopada 2021.). 
će pribavljanje sredstava za njihovo održavanje i financiranje iz različitih izvora, uključujući i sredstva Europske unije, te evidentiranje predmetnih građevina u informacijski sustav prostornog uređenja (ISPU), čime se olakšava i unapređuje praćenje stanja u prostoru, pravni promet nekretninama i povećava pravna sigurnost, izrada prostornih planova i drugih propisa i dokumenata vezanih uz prostor i nadzor građevinske inspekcije. ${ }^{91}$

Iako sam Obrazac ne sadržava detaljniju razradu problematike ozakonjenja infrastrukture na pomorskom dobru koja se namjerava postići navedenim nacrtom prijedloga zakona, svakako je važno istaknuti da se u točki 4. Obrasca, koja se odnosi na moguća rješenja za postizanje opisanog cilja, navodi da ne postoji nenormativno rješenje kojim bi se postigao takav ishod. Dakle, iz navedenog se jasno iščitava da sada ne postoji odgovarajući način za ozakonjenje nezakonito izgrađene infrastrukture na pomorskom dobru, već je to potrebno urediti posebnom normom.

\section{MOGUĆI SMJEROVI U RAZVOJU REGULATIVE OZAKONJENJA SUPRASTRUKTURNIH GRAĐEVINA U LUKAMA NAUTIČKOG TURIZMA}

Što možemo naučiti iz neuspjelog pokušaja ozakonjenja nezakonito izgrađenih infrastrukturnih građevina na pomorskom dobru? I što se može učiniti drukčije kada je riječ o suprastrukturi?

Prvo, valja razlučiti zašto se uopće ima odvojiti ozakonjenje infrastrukture od suprastrukture na pomorskom dobru. Pravna logika iza razdvajanja infrastrukture i suprastrukture po pitanju ozakonjenja i davanja primata infrastrukturi je jasna. Infrastruktura nepobitno služi općem interesu, u pravilu je riječ o objektima čiji su investitori bili javne osobe te bi se sama problematika trebala lakše rješavati od pitanja suprastrukture na pomorskom dobru, poglavito uzevši u obzir da je nerijetko prisutna i suprastruktura čiji su investitori (ne)ovlašteno bili privatne osobe. Posebno normativno uređenje ozakonjenja nezakonito izgrađene suprastrukture na pomorskom dobru se, svakako nakon uspješnog rješavanja problematike infrastrukture, nameće kao sljedeće na redu. Tome trebaju također prethoditi stručne analize i javna rasprava, ali i konačno zauzimanje stava postoje li stečena prava i legitimna očekivanja glede pomorskog dobra, odnosno, ako postoje, što je zakonodavcu, a posljedično i praksi, s njima činiti. ${ }^{92}$

91 Točke 3.1. i 3.2. obrasca prethodne procjene za zakon o postupanju s nezakonito izgrađenom infrastrukturom.

92 Više vidi Ljubetić, op. cit. u bilj. 1, str. 81 - 121. 


\section{ZAKLJUČAK}

Iz danog pregleda i analize uređenja legalizacije građevina na pomorskom dobru razvidno je da je i dalje riječ o složenim i dalekosežnim postupcima, bilo da je riječ o izgradnji nove građevine ili legalizaciji postojeće. U potonjem slučaju, naravno, ako u međuvremenu građevinska inspekcija nije provela nadzor i izdala rješenje o uklanjanju građevine. Nadalje, unatoč naporima učinjenim da se proširi krug ovlaštenika za ishodovanje potrebnih dozvola i dalje postoji niz pravnih subjekata neosnovano isključenih od te mogućnosti. Tako bi se svakako jedinicama lokalne samouprave u okviru brige o pomorskom dobru mogla priznati veća prava glede mogućnosti izgradnje novih odnosno legalizacije postojećih građevina na pomorskom dobru. Čak i neuspjelim Prijedlogom zakona podnošenje zahtjeva priznaje se vlasniku te upravitelju konkretne građevine. Također, pregledom postojećih propisa, a posebice Zakona o prostornom uređenju i pratećih propisa, nejasno je zašto su dane tako ograničene mogućnosti legalizacije objekata u lukama nautičkog turizma s obzirom na to da brojni objekti datiraju još iz 80-ih godina prošlog stoljeća, kada ni sami propisi o prostornom planiranju nisu nametali brojna danas propisana ograničenja. Donošenjem Zakona o postupanju s nezakonito izgrađenim zgradama uveden je različit pravni pristup prema građevinama izgrađenim na pomorskom dobru i izvan njega. Zakon o gradnji ima različit pravni tretman građevina izgrađenih na pomorskom dobru i izvan njega. Stoga se čini neopravdanim ostaviti u primjeni isti pravni tretman svih građevina sukladno Zakonu o građevinskoj inspekciji. To ne znači da bi se i na građevine izgrađene na pomorskom dobru imale primijeniti odredbe istovjetne onima u Zakona o postupanju s nezakonito izgrađenim zgradama, no svakako valja razmisliti o tome da se napravi korak prema mogućnosti ozakonjenja građevina u tom smjeru. Rješenje bi predstavljao posebni zakon koji bi regulirao pitanje postupanja s nezakonito izgrađenim suprastrukturnim i infrastrukturnim građevinama na pomorskom dobru. No, uputno je pričekati razvoj pravnih rješenja za pitanje infrastrukture kako bi se na osnovi najboljih primjenjivih rješenja dobila odgovarajuća podloga za daljnje postupanje za problematiku nezakonito izgrađene suprastrukture na pomorskom dobru, normativno i u praksi. Pritom bi se primjena Zakona o građevinskoj inspekciji za već izgrađene objekte na pomorskom dobru u lučkom području prije stupanja na snagu navedenog zakona, koji nemaju izvršnu građevinsku dozvolu ili glavni projekt odnosno drugi akt, trebala odgoditi do konkretnog rješavanja navedene problematike putem posebnog zakona. 


\section{LITERATURA}

\section{Knjige i članci}

Bolanča, D., Problem stvarnih prava na pomorskom dobru (bitne novine hrvatskoga pomorskog zakonodavstva), Poredbeno pomorsko pravo, vol. 54, 2015., str. 327 - 358.

Britvić Vetma, B.; Stančić Vidrač, E., Postupak ozakonjenja nezakonito izgrađene zgrade, Zbornik radova Veleučilišta u Šibeniku, br. 1-2, 2015., str. 149 - 164.

Frković, S., Nekretnine na pomorskom dobru i otocima, izlaganje s 13. Foruma poslovanja nekretninama, HGK, Rovinj, 2008., str. I - 22.

Gavella, N.; Josipović T.; Gliha, I.; Belaj, V.; Stipković, Z., Stvarno pravo, II. izmijenjeno i dopunjeno izdanje, svezak 1., Narodne novine, Zagreb, 2007.

Gavella, N.; Alinčić, M.; Klarić, P.; Sajko, K.; Tumbri, T.; Stipković, Z.; Josipović, T.; Gliha, I., Hrvatsko građanskopravno uređenje i kontinentalnoeuropski pravni krug, 2. izdanje, Pravni fakultet, Zagreb, 1994.

Hlača, V.; Nakić, J., Zaštita pomorskog dobra u Republici Hrvatskoj, Poredbeno pomorsko pravo, vol. 49, 2010., str. 493 - 529.

Jelavić, A., Pravni položaj pomorskog dobra, Naše more, vol. 59, br. 1-2, 2012., str. $22-35$.

Jug, J., Stvarna prava na pomorskom dobru?, Zbornik Pravnog fakulteta Sveučilišta u Rijeci, vol. 34, br. 1, 2013., str. 277 - 305.

Jug Dujaković, M.; Božić Fredotović, K., Granice vlasničkih ovlaštenja glede nekretnina izgrađenih na morskoj obali Republike Hrvatske, Naše more, vol. 56, br. 3-4, 2009., str. $138-144$.

Ljubetić, S., Pomorsko dobro i zemlijišne knjige, Pravni fakultet Sveučilišta u Zagrebu, Zagreb, 2019.

Ljubetić, S., Pomorsko dobro i luke nautičkog turizma, u: Zbornik 57. susreta pravnika u gospodarstvu, Opatija, 2019., str. 309 - 332.

Marin, J., Koncesija i pravo vlasništva na objektima izgrađenima na pomorskom dobru, Pravo u gospodarstvu, vol. 37, br. 2, 1998., str. $246-257$.

Nakić, J., Određivanje granice pomorskog dobra u Republici Hrvatskoj - de lege lata $i$ de lege ferenda, doktorska disertacija, Pravni fakultet, Split, 2012.

Nakić, J., Pomorsko dobro - opće ili javno dobro?, Zbornik radova Pravnog fakulteta u Splitu, vol. 53, br. 3, 2016., str. 797 - 832.

Paunović, A., Uloga turističkih subjekata u izgradnji struktura za povremeno stanovanje (hoteli, marine, kampovi), u: Kuća pokraj mora: povremeno stanovanje na hrvatskoj obali, knjiga 31., Institut društvenih znanosti "Ivo Pilar" i Ministarstvo za- 
štite okoliša, prostornog uređenja i graditeljstva Republike Hrvatske, Zagreb, 2006., str. 137 - 154.

Perkušić, A.; Petrinović, R.; Perkušić, Z., Stjecanje i zaštita posjeda na pomorskom (općem) dobru - de lege lata - de lege ferenda (poseban osvrt na prijedlog novog Zakona o pomorskom dobru i morskim lukama), Poredbeno pomorsko pravo, vol. 49, 2010., str. 531 - 554.

Potsiou, C.; Boulaka, I., Informal development in Greece: New legalisation for Formalization, the Chances for Legalization and the Dead Capital, International Federation of Surveyors, 2012., str. 1 - 19, dostupno na http://www.fig.net/pub/fig2012/ papers/ts09k/TS09K_potsiou_boulaka_5514.pdf.

Sanjković, L.; Kemeter, D., Ozakonjenje nezakonito izgrađenih zgrada u Republici Hrvatskoj, Zbornik radova Međimurskog veleučilišta u Čakovcu, vol. 8, br. 1, 2017, str. $71-78$.

Tomić, J., Legalizacija nezakonito izgrađenih zgrada, Tehnički glasnik, vol. 9, br. 2, 2015., str. 186 - 197.

Vladušić, J., Određivanje granica pomorskog dobra u hrvatskom pravu, Zbornik radova Pravnog fakulteta u Splitu, vol. 46, br. 1, 2009., str. 219 - 246.

Vojković, G., Pomorsko dobro i koncesije, Hrvatski hidrografski institut, Split, 2003.

Vuković, A.; Luković, T., Maritime domain as public property, the results of strategic planning of national economy development, or?, DIEM - Dubrovnik International Economic Meeting, University of Dubrovnik, vol. 3, br. 1, 2017., str. 346-360.

\section{Propisi}

Ustav Republike Hrvatske, Narodne novine, br. 56/1990, 135/1997, 8/1998, 113/2000, 124/2000, 28/2001, 41/2001, 55/01, 76/2010, 85/2010 i 5/2014.

Pomorski zakonik, Narodne novine, br. 17/1994, 74/1994 i 43/1996.

Zakon o vlasništvu i drugim stvarnim pravima, Narodne novine, br. 91/1996, 68/1998, 137/1999, 22/2000, 73/2000, 129/2000, 114/2001, 79/2006, 141/2006, 146/2008, 38/2009, 153/2009, 143/2012 i 152/2014.

Zakon o pomorskom dobru i morskim lukama, Narodne novine, br. 158/2003, 100/2004, 141/2006, 38/2009, 123/2011, 56/2016 i 98/2019.

Zakon o prostornom uređenju i gradnji, Narodne novine, br. 76/2007, 38/2009, 55/2011, 90/2011, 50/2012 i 55/2012.

Zakon o općem upravnom postupku, Narodne novine, br. 47/2009.

Zakon o upravnim sporovima, Narodne novine, br. 20/2010, 143/2012, 152/2014, 94/2016 i 29/2017. 
Zakon o postupanju s nezakonito izgrađenim zgradama, Narodne novine, br. 86/2012, 143/2013, 65/2017 i 14/2019.

Zakon o prostornom uređenju, Narodne novine, br. 153/2013, 65/2017, 114/2018 i $39 / 2019$.

Zakon o gradnji, Narodne novine, br. 153/2013, 20/2017, 39/2019 i 125/2019.

Zakon o građevinskoj inspekciji, Narodne novine, br. 153/13 i 115/18.

Zakon o pružanju usluga u turizmu, Narodne novine, br. 130/2017, 25/2019, 98/2019 i 42/2020.

Zakon o strateškim investicijskim projektima Republike Hrvatske, Narodne novine, br. 29/2018 i 114/2018.

Zakon o upravljanju državnom imovinom, Narodne novine, br. 52/2018.

Uredba o postupku utvrđivanja granice pomorskog dobra, Narodne novine, br. 8/2004 i 82/2005.

Pravilnik o jednostavnim i drugim građevinama i radovima, Narodne novine, br. 112/2017, 34/2018, 36/2019, 98/2019 i 31/2020.

Pravilnik o kategorizaciji luke nautičkog turizma i razvrstavanju drugih objekata za pružanje usluga veza i smještaja plovnih objekata, Narodne novine, br. $120 / 2019$.

\section{Sudska praksa}

Vrhovni sud Republike Hrvatske, rješenje, broj Gzz-131/03-2, od 2. srpnja 2003., dostupno na https://www.iusinfo.hr/sudska-praksa/VSRH2003GzzB131A2.

Visoki trgovački sud Republike Hrvatske, rješenje, posl.br. P̌̌ 8457/2016-2, od 20. siječnja 2017., dostupno na https://www.iusinfo.hr/sudska-praksa/ VTSRH2016PzB8457A2.

Visoki upravni sud Republike Hrvatske, presuda, posl.br. Usž-374/16-2, od 2. ožujka 2016. godine, dostupno na https://www.iusinfo.hr/sudska-praksa/ UpSRH2016UszB374A2.

\section{Ostalo}

Mišljenje Ministarstva graditeljstva i prostornog uređenja, Klasa: 360-01/1202/411, Ur.broj: 531-01-12-2, od 13. rujna 2012. godine, dostupno na https:// www.iusinfo.hr/misljenja-i-tumacenja/MMIN201D20120913N52.

Mišljenje Ministarstva graditeljstva i prostornog uređenja, Klasa: 360-01/1402/55, Ur.broj: 531-01-14-2, od 4. veljače 2014. godine, dostupno na https:// www.iusinfo.hr/misljenja-i-tumacenja/MMIN201D20140204NI28. 
Summary

\section{Sanja Ljubetić}

\section{CHALLENGES OF LEGALIZATION OF BUILDINGS IN NAUTICAL TOURISM PORTS}

The paper analyzes the problems and challenges faced by investors in nautical tourism ports when obtaining permits for existing buildings, which due to the historically unresolved legal situation do not have the necessary permits. An overview of the regulation of the institute of maritime domain and the legal status of buildings on the maritime domain is given. Special attention in the paper is paid to the issue of legalization of buildings in accordance with the definition of port superstructure in nautical tourism ports contained in the general provisions of the Act on Maritime Property and Seaports. Furthermore, the paper clarifies who can be considered an investor for the construction of buildings on the maritime domain, and presents the views in practice on the possible application of the Act on the Treatment of Illegally Constructed Buildings. An overview and assessment of the regulation and the legal and economic consequences of the existing regulation is presented. New directions in the development of legalization regulations for buildings on the maritime domain are considered. The paper ends with a conclusion summarizing the above points of research, as well as an assessment of the normative situation. Finally, proposals aimed at better legal regulation of the researched subject are given.

Key words: maritime domain, port area, nautical tourism ports, legalization of buildings

\footnotetext{
Sanja Ljubetić, Ph. D., Legal Representative, Adriatic Croatia International Club, Rudolfa Strohala 2, 51000 Rijeka; sanja.ljubetic@aci-club.hr;

ORCID ID: orcid.org/0000-0002-0110-3998
} 